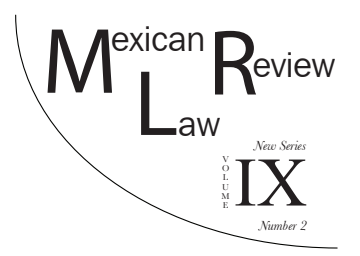

\title{
MEXICO: A FAILED STATE OR A GRIMINAL STATE? THE NESTORA SALGADO CASE
}

\author{
Ricardo Arturo Lagunes Gasca*
}

Abstract. For decades, the people in the Mexican state of Guerrero have been immersed in poverty, insecurity, and militarization. Accordingly in 1995, almost a year after the Zapatista National Liberation Army (EZLN) uprising, a community police corporation was formed with members of indigenous communities, in order not only to protect the population against organized and regular crime but also to administer justice with the legal grounds provided by the International Labour Organization Convention 169. Since then, many members of the Guerrero community police have been incarcerated for political reasons. One of them is Nestora Salgado, who was illegally detained by the Mexican army and incarcerated in a high security prison in Nayarit for almost 20 months. In December 2015, the United Nations Working Group on Arbitrary Detention deemed the detention of Nestora Salgado as illegal and arbitrary, and requested her immediate release.

KEY wORDs: United Nations, human rights, Guerrero, Mexico, human rights defenders, communitary police.

Resumen. Por décadas, el pueblo del Estado Mexicano de Guerrero ha estado sumergido en la pobreza, inseguridad y militarización. Por esa razón en 1995 , casi un año después del alzamiento del Ejército Zapatista de Liberación Nacional, se fundó la policía comunitaria compuesta por las comunidades indígenas,

* The author is a lawyer graduated from the National Autonomous University of Mexico (UNAM). He received a master's degree in Human Rights Protection from Alcalá University in Spain. Before starting his own human rights practice, the author has collaborated in human rights organizations such as Fray Matías de Córdova, Fray Bartolomé de las Casas and the Center for Justice and International Law (CEJIL). He has also collaborated with the Human Rights Clinic of Seattle University School of Law in cases before the Inter-American Commission of Human Rights. 
Esta revista forma parte del acervo de la Biblioteca Jurídica Virtual del Instituto de Investigaciones Jurídicas de la UNAM

con el objetivo no solo de proteger a la población frente al crimen organizado y el crimen en general sino, también, para administrar justicia con la base legal que otorga el Convenio 169 de la Organización Internacional del Trabajo. Desde esa época hasta la fecha, muchos integrantes de la policía comunitaria de Guerrero han sido encarcelados por motivos políticos, una de ellos es Nestora Salgado García, quien fue detenida ilegalmente por el ejército mexicano y llevada a un penal de máxima seguridad en Nayarit por aproximadamente 20 meses. En diciembre de 2015 el Grupo de Trabajo de Naciones Unidas sobre Detención Arbitraria determinó que México detuvo de manera ilegaly arbitraria a Nestora Salgado y solicitó su liberación inmediata.

Palabras Clave: Naciones Unidas, Derechos Humanos, Guerrero, México, Defensores de Derechos Humanos, policía comunitaria.

\section{TABle of Contents}

I. INTRODUCTION ........................................................................ 142

II. BRIEF BACKGROUND OF COMMUNITY POLICE OF GUERRERO .................. 143

III. OPINION 56/2015 OF UNITED NATIONS WORKING GROUP ON ARBITRARY DETENTION ABOUt Nestora SALGado's Case.

\section{INTRODUCTION}

Even though Mexico has ratified almost 210 human rights treaties, ${ }^{1}$ and has recently enacted a constitutional reform (2011), violations of human rights are getting worse. This social and political crisis was documented and reported by the Inter-American Commission on Human Rights in the special report on Mexico $^{2}$ as a result of an in locu visit that took place in SeptemberOctober 2015, ${ }^{3}$ and by the United Nations High Commissioner for Human Rights. ${ }^{4}$

At the end of his on-site visit to Mexico, the High Commissioner for Human Rights reported alarming rates of violence occurring since 2006, ${ }^{5}$

\footnotetext{
1 National Supreme Court of Mexico. http://www2.scjn.gob.mx/red/constitucion/ TI.html

2 Special Report of the Inter-American Comission of Human Rights http://www.oas. org/es/cidh/informes/pdfs/Mexico2016-es.pdf. [Fecha de consulta: 31 de marzo de 2016].

3 Visita in locu of the Inter-American Comission of Human Rights http://www.oas.org/ es/cidh/actividades/visitas/mexico2015.asp. [Fecha de consulta: 31 de marzo de 2016].

4 Statement of the United Nations High Comissioner for Human Rights on his visit to Mexico, October, 2015, http://www.hchrorg.mx/index.php?option=com $\mathrm{k} 2 \&$ view $=$ item\&id $=767$ :declaracion-del-alto-comisionado-de-la-onu-para-los-derechoshumanos-zeid-ra-ad-al-hussein-con-motivo-de-su-visita-a-mexico\&Itemid=265. [Fecha de consulta: 31 de marzo de 2016].

${ }^{5} \mathrm{Id}$.
} 
although Mexico is not yet considered a country technically involved in an armed conflict. For instance 151,233 people were killed between December 2006 and August 2015 including migrants in transit through Mexican territory; since 2007 there have been at least 26,000 cases of missing people, most of them probably related to enforced disappearances.

From April 21 to May 2, 2014, the United Nations Special Rapporteur on Torture made an on-site visit to Mexico. As a result, he addressed a final report ${ }^{6}$ to the Human Rights Council stating that torture and inhuman treatments are widespread from the detention of a person until the moment he or she is brought before a prosecutor or a judge. Special Rapporteur on Torture stressed the weakness of the safeguards to detect or prevent the torture of the detainees while in custody, and above all, a lack of an effective investigation. $^{7}$

In the last two years, Mexico has captured international attention, unfortunately due to several high impact cases of human rights violations: the forced disappearance of 43 students from the Raúl Isidro Burgos School (Ayotzinapa), as well as the Tlatlaya, Tanhuato, and Apatzingan cases, among others.

\section{BRIEF BACKGROUND OF COMMUNITY POLICE OF GUERRERO}

Guerrero has undergone several periods of high violence, repression, and military occupation. Since the 1960s, leftist guerrilla groups led by peasants and rural teachers have demanded that their basic human rights be respected and guaranteed.

In 1995, driven by the political and economic crisis, indigenous communities of Tlapanecos, Mixtecos, Nahuas, and Amuzgos, among others, from the Costa Chica and the mountain region in Guerrero, formed a community police force aimed at stopping insecurity, corruption and impunity. ${ }^{8}$

Best known as the Comunitaria, this police force was able to reduce local violence and insecurity in a short time. Afterwards it initiated a process to implement a regional justice system based on indigenous law. ${ }^{9}$ Due to the inefficiency of the judicial system the communities decided to create their own and autonomous justice system. Therefore, in 1998 the Coordinadora Regional

6 Final Report, United Nations Special Rapporteur on Torture, on-site visit to Mexico, http://sintortura.mx/wp-content/uploads/2015/03/A_HRC_28_68_Add_3_SPA.pdf. [Fecha de consulta: 1 de abril de 2016].

7 Id., paragraph 77.

8 Raúl Romero Gallardo, La Policía Comunitaria de Guerrero: un sistema alternativo de seguridady justicia, REVISTA Digital UNIVERSITARia, UNAM, [fecha de consulta: 1 de abril de 2016], http:// www.revista.unam.mx/vol.15/num9/art68/.

9 María Teresa Sierra, CIESAS, [fecha de consulta: 1 de abril de 2016], https://nacla. $\mathrm{org} /$ article/indigenous-justice-faces-state-community-police-force-guerrero-mexico. 
de Autoridades Comunitarias was established with the role to administer justice and enforce the law. ${ }^{10}$

The government responded with repression against the communities. In 2002, all the community authorities were incarcerated and in August 2007 many orders were issued to arrest community police members. ${ }^{11}$

In April 2011, the government of Guerrero issued the State Law 701 acknowledging the rights and culture of indigenous peoples, ${ }^{12}$ and referring to the Comunitaria and Coordinadora as part of the justice system of the state.

Notwithstanding the legal recognition made in the Guerrero State Law 701, in August 2013 Nestora Salgado and other members of the community police of Olinalá, Guerrero, were illegaly and arbitrarily arrested. Many of them are still in prison.

\section{Opinion 56/2015 of United Nations Working Group on Arbitrary Detention about Nestora Salgado’s case}

Nestora Salgado was arrested in August 2013 for her courageous community work in the small indigenous village of Olinalá, Guerrero. Salgado was a leader of a community-policing group that legally forms part of state law enforcement, and had the express approval of Guerrero's governor.

Authorities abruptly changed their position, however, when the group arrested a local official for committing a crime. Salgado was immediately seized by military forces and flown nearly 1,000 kilometers away to the prison of El Rincon, in Nayarit. She was denied visits from her chosen attorney for nearly a year.

Salgado was refused bail, and has lived in solitary confinement 24 hours a day. She has also been denied necessary medical treatment and clean water.

In November 2013, the Human Rights Clinic at Seattle University School of Law requested the United Nations Working Group on Arbitrary Detention (UNWGAD or Working Group) to issue a legal opinion confirming Nestora Salgado's arbitrary and illegal deprivation of liberty.

In December 2015, having analysed the information provided by the $\mathrm{Hu}$ man Rights Clinic and the Mexican government, the UNWGAD issued a legal opinion. ${ }^{13}$

10 Giovanna Gasparello, Policía Comunitaria de Guerrero, investigación y autonomía, PolítiCA $Y$ CULtura 32 (Fall, 2009), [Fecha de consulta: 1 de abril de 2016]. http://www.scielo.org.mx/ pdf/polcul/n32/n32a4.pdf.

$11 \mathrm{Id}$.

12 See http://guerrero.gob.mx/leyesyreglamentos/ley-numero-701-de-reconocimientoderechos-y-cultura-de-los-pueblos-y-comunidades-indigenas-del-estado-de-guerrero/ (Article 35-42). [Fecha de consulta: 2 de abril de 2016].

13 See http://www.ohchr.org/Documents/Issues/Detention/Opinions2015AUV/ Opini on\%202015\%2056_Mexico_SalgadoGarcia_AUV\%20.pdf. [Fecha de consulta: 2 de abril de 2016]. 
The Working Group stated that the source is reliable and has a high standard of credibility, on the basis that the allegations are thoroughly corroborated with the response of the Mexican government.

Additionally, it acknowledged Nestora Salgado as a defender of community human rights and added that she was arrested despite the fact that there were no criminal charges against her. It highlighted the circumstance that a federal court acquitted Nestora Salgado on the same facts she was accused of at the local level, an absolute contravention of the non bis in idem principle.

There is no doubt, says the UNWGAD, that the arrest and detention without formal imputation of criminal charges is illegal and arbitrary. Also, it points out as a motive of concern the role of the Mexican army in the detention of civilian people.

Furthermore, the UNWGAD emphasized that Nestora Salgado during her detention did not have access to legal representation and she was not presented before a judge or a court in order to decide about the legality of the detention. In this case the Mexican government did not observe the basic right to a fair trial.

As well, it remarks the fact that Nestora Salgado has been persecuted in retaliation for her human rights work in favor of indigenous peoples.

Finally, the UNWGAD concludes requesting that the Mexican government solve this case releasing Nestora Salgado and providing her an appropriate compensation.

The UNWGAD legal opinion was the first resolution not only at international level but also at the local one, to recognize the severe human rights violations in Nestora Salgado's case since she was arrested, excluding her of any judicial and legal protection as a punishment for her work in favor of indigenous communities.

Doubtlessly, this international legal opinion played a key role in putting Mexican government under pressure to release Nestora Salgado. She was thus freed in March 18, 2016, after almost two years and seven months of unjust imprisonment. 